\title{
5-A-SIDE FOOTBALL FOR INDIVIDUALS WITH VISUAL IMPAIRMENTS: A REVIEW OF THE LITERATURE
}

\author{
José Martín Gamonales ${ }^{1 *}$, Jesús Muñoz-Jiménez ${ }^{1,2}$, Kiko León-Guzmán ${ }^{1,2}$, and Sergio J. Ibáñez ${ }^{1}$
}

Received: 19 ${ }^{\text {th }}$ September 2017; Accepted: 10 ${ }^{\text {th }}$ January 2018; Published: 18 November 2018

\begin{abstract}
The present study aims to conduct a structured literature review based on the results found concerning the term 5 -a-side football for individuals with visual impairments. The following keywords were used as descriptors in the reference search: 5-a-side football, football, blind and football for the blind and soccer for the blind. The words were introduced in English, Portuguese and Spanish databases. In order to narrow the search, four inclusion criteria were introduced: i) Mention at least one characteristic of 5-a-side football for individuals with visual impairments, ii) Any type of document is included, iii) Only documents in full-text or abstract version and iii) Written in English, Portuguese or Spanish. After the review process, 40 papers were found, classified into eleven Sport Science disciplines. In conclusion, literature on 5-a-side football for individuals with visual impairments has addressed different research topics in last years.
\end{abstract}

Keywords: blindness; disability sport; team sports; Performance analysis; fútbol para ciegos; Futebol para cegos

\section{Introduction}

There are a large variety of research topics concerning adapted physical activity (APA). The first studies were mostly conducted from disciplines related to sport sciences, such as physiology or biomechanics, and oriented to wheelchair sports. However, the term APA has not only been understood as an interdisciplinary body of knowledge included in sport sciences, but also as a theoretical framework of reference for research, programming and design of strategies which make physical activity and sport more accessible to people with disabilities (DePauw \& Sherrill, 1994). Subsequently, from areas such as psychology, sociology or medicine (DePauw \& Doll-Tepper, 2000; Doll-Tepper \& DePauw, 1996), research spread to other types of disability, sport modalities and fields of application. Reynolds (1984) had already suggested improvements in the existing research related to APA fields relatively new at that moment, namely therapeutic recreation and adapted physical education.

Nowadays, APA is one of the disciplines included in the Directory of Sport Sciences published by the International Council of Sport Science and Physical Education (ICSSPE; Borms, 2008). This regard is due to the large number of related fields, which have been objects of research lately, including many sport modalities and impairments. Thus, studies, which aim to organize and structure these research topics, may be found in the literature. Other studies are related to the development of APA research, either focusing on the analysis of its characteristics and excellence level (Pérez-Tejero, 2009) or related to the improvement of APA research quality. This is the case of the papers published in Adapted Physical Activity Quarterly (APAQ) journal during the years 1997 and 1998. They offer a guide of most frequent APA topics: sports for the disabled or development and implementation of new tools for inclusion/integration (Sherrill \& O'Connor, 1999). In this regard, Reid \& Prupas (1998) show the evolution, since their creation, of the most important APA areas suggested by the Research Subcommittee of the Committee on Sports for the Disabled of the United States. The main lines of APA research in Spain are: motor control and learning, psychology, didactics 
and physical education, sport biomechanics and ergonomics, sport training and adapted sport (Mendoza, 2007). In line with this, Pérez-Tejero, Reina-Vaíllo \& Sanz (2012) analyzed the current state of application and the scientific applications of physical activity for the disabled in Spain and determined the main development areas between 2000 and 2012. They concluded that the main research areas were: physical education and teaching of physical activity and sport, sports and physical activity practices, social sciences applied to sports and physical activity practice and, lastly, exercise physiology. APA is one of the leisure practices, which has grown the most along the century.

Within APA, sport for the disabled in general and football in particular has become one of the most popular sports among people with visual impairment around the world (Gamonales, 2016). Football for the blind and partially sighted incorporated into the International Blind Sports Federation (IBSA) in 1996, with the creation of the Football Subcommittee. It includes two types of football: B1 for footballers who are completely blind, and B2 / B3 for players who are partially sighted. B1 football, known as 5-a-side football for individuals with visual impairments, has become one of the most attractive sports on the Paralympic Games program following its debut at the Athens 2004 Games (IBSA, 2017).

5-a-side football for individuals with visual impairments is regulated by the rules of the International Federation of Association Football (FIFA), with some specific adaptations which allow blind footballers to play (Magno, Morato, Bilzon \& Duarte, 2013). It is a cooperation-opposition sport, which is played on a common field with simultaneous participation of all players involved (Hernández, 2005). In the current laws of the game (2014-2017), 5-a-side football for the blind is defined as an essential tool for the continuous rehabilitation that a blind person needs (ISBA, 2017). It is an adaptation of conventional futsal, the aim of which is to make specific football actions easier to perform for individuals with visual impairments (Morato, 2007). Scientific literature regarding 5a-side football for the blind is recent (Gamonales, León, Muñoz, González-Espinosa \& Ibáñez, 2018). A large proportion of these studies is not very accurate and is mainly focused on dissemination. Nevertheless, a slight increase in the number of papers, which have been indexed in databases such as Web of Science (WOS), has occurred in the last years. In this regard, the work of Giagazoglou, Katis, Kellis \& Natsikas (2011), which describes the kinematic differences in kicking between blind and sighted players, must be highlighted. Magno et al. (2013) analyze the main injury characteristics of Brazilian blind footballers, while Suárez (2014) analyzes the role of the guide.

Nonetheless, studies related to performance indicators of 5-a-side football are scarce. Another type of studies, which are indexed in other databases, such as Google Scholar, may be found. The first approaches of sport sciences to 5-a-side football may be found in these studies, published as books or journal articles. De Moura, Calsavara, Da Silva, Da Mota \& Moreira (2015) conducted a review on 5-a-side football for individuals with visual impairments. They performed a search in the databases PubMed, SPORTDiscus, WOS and Scopus, as well as in the electronic library Scielo and Google Scholar. They finally included nine papers, which had been originally published in Portuguese or English.

Therefore, in light of the lack of review studies, and having analyzed the different databases, it seems convenient to conduct a new literature review which completes the state of the art in the research of this sport discipline and enables true, verifiable and relevant conclusions to be drawn (Gutiérrez \& Oña, 2005). In other words, to conduct a systematic review on the variety of topics addressed in the published research, with the aim to analyze and learn about the scientific production related to the sport modality under study: 5-a-side football for individuals with visual impairments. This general aim becomes more specific in the following two: i) to conduct a systematic literature review based on the results obtained for the terms disability and 5-a-side football for the blind, and ii) to group the studies related to 5-a-side football for individuals with visual impairments according to their research topic. In order to do this, the taxonomy proposed in the Directory of Sport Sciences (Borms, 2008) will be applied. 


\section{Materials and Methods}

\section{Design}

This study lies under theoretical research, since it constitutes an update on the literature regarding 5-a-side football for individuals with visual impairments, using systematic data gathering and study selection processes (Ato, López \& Benavente, 2013). It is, therefore, a literature review with the aim to analyze and learn about the existing manuscripts related to the sport modality under study.

\section{Inclusion criteria}

Keywords in different languages were used for the search. In English: 5-a-side football, football, blind; in Portuguese: futebol para cegos; and in Spanish: fútbol para ciegos. These terms were used in English, Portuguese or Spanish in order to collect as many studies as possible concerning 5-a-side football for individuals with visual impairments. The documents were selected to become part of the sample if they met the inclusion criteria listed in Table 1.

Table 1. Criteria for inclusion or exclusion of documents

\begin{tabular}{cc}
\hline No. & Inclusion criteria \\
\hline 1 & It mentions at least one characteristic of 5-a-side football for individuals with visual \\
& impairments (min. 50 words). \\
2 & It may be any type of document. \\
3 & Either the full-text version or an abstract is available. \\
4 & It is written in English, Portuguese or Spanish. \\
\hline & Exclusion criteria \\
\hline 5 & When "double-blind" refers to a scientific method for peer review in football or soccer \\
7 & studies for people without visual impairment. \\
8 & It cannot be referenced. \\
\hline
\end{tabular}

\section{Sample}

The sample consisted of different types of documents: books, book chapters, theses and dissertations, congress and scientific meeting publications, scientific journal articles and patent documents. From the 1004 documents obtained in the first search, 964 were excluded and 40 met the inclusion criteria and were, therefore, selected. Additionally, the keywords included in the documents were taken into account. A set of terms related to the topic of the study was assigned to those texts, which did not contain keywords.

\section{Variable codification}

The selected documents were classified according to the following criteria: author/s, year, keywords, type of document, Sport Science discipline, quality of research (peer review) and description.

- Author/s: first surname or scientific name of each author of the selected bibliographic reference.

- Year: official year of publication.

- Keywords: terms included in the document.

- Type of document: doctoral theses (T), books (B), book chapters (BC), academic projects (AP), congress and scientific meeting publications (CSM), journal articles (JA) and patent documents (PD).

- Sport Science discipline: the different documents were grouped according to the Directory of Sport Science of the International Council of Sport Science and Physical Education (ICSSPE; Borms, 2008)). This directory includes the seventeen disciplines which constitute the body of 
knowledge of Sport Science (Table 2) and which permitted the classification of the bibliographic references.

- Quality of research (peer review): The documents were classified according to their scientific quality, considering whether they were subjected to peer review before publication.

- Description: A brief summary of the document was included.

Table 2. Sport Science Disciplines approved by ICSSPE (Borms, 2008)

\begin{tabular}{ccc}
\hline Nr. & Disciplines & Key \\
\hline 1 & Adapted Physical Activity Science & APA \\
2 & Sport Biomechanics & SB \\
3 & Coaching Science & CS \\
4 & Motor Behavior & MB \\
5 & Sports Law & SL \\
6 & Motor Development, Motor Control and Motor Learning & MD \\
7 & Sport Philosophy & SPh \\
8 & Sport and Exercise Physiology & SEPh \\
9 & Sport Management & SMa \\
10 & Sport History & SH \\
11 & Sport Information & SI \\
12 & Kinanthropometry & K \\
13 & Sport Medicine & SMe \\
14 & Sport and Leisure Facilities & SLF \\
15 & Sport Pedagogy & SPe \\
16 & Sport and Exercise Psychology & SEPs \\
17 & Sport Sociology & SS \\
\hline
\end{tabular}

\section{Study selection process and data analysis}

The success of a good literature review resides in appropriate planning (Thomas, Silverman \& Nelson, 2015). By doing so, the steps and strategies followed during the review process allow relevant conclusions to be drawn. The literature search process used in this study is represented in Figure 1.

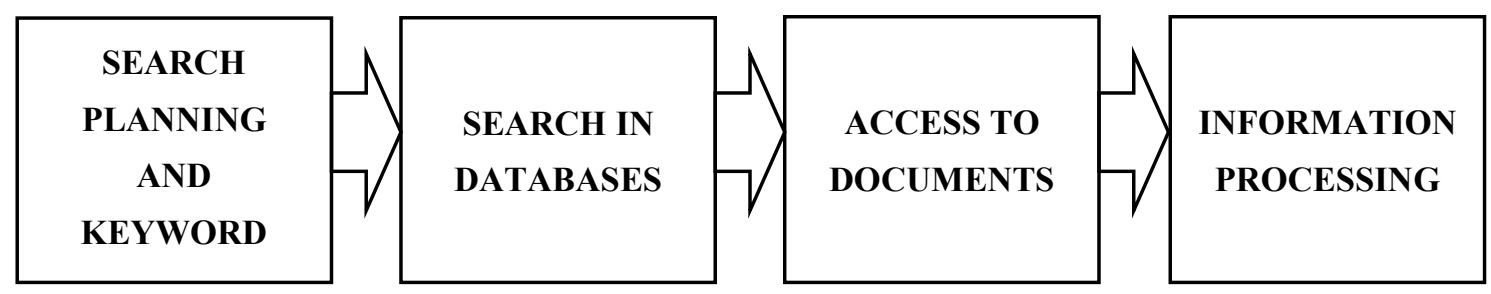

Figure 1. Diagram of the literature search process

\section{Search planning and keyword selection}

A set of keywords was selected in order to find as many documents as possible. Four researchers developed the documents search individually and independently, using the same criteria. The descriptors used were: 5-a-side football, football, blind, futebol para cegos and fútbol para ciegos. Additionally, the inclusion criteria (Table 1) for the documents to be selected were determined.

\section{Search in databases}

Seven literature search processes were conducted in the most relevant electronic databases: WOS, Scopus, SPORTDiscus, PubMed and Google Scholar. Similar search patterns were used in every process: words in English, Portuguese and Spanish. The AND - E - Y connectors were used between keywords, which was essential to obtain more specific results. Moreover, quotation marks 
(“...") were used in Google Scholar to narrow the search. The documents, which met the inclusion criteria, were selected for this study. Figure 2 shows the keywords used for the search every time, together with the number of documents found. These documents were filtered according to the inclusion criteria in order to obtain valid documents. Subsequently, a second filter on the valid documents was applied in order to avoid duplicates resulting from the seven search processes.

Databases

Keywords used

Number of documents

Number of valid

Number of non-

per keyword/s documents

duplicate

documents

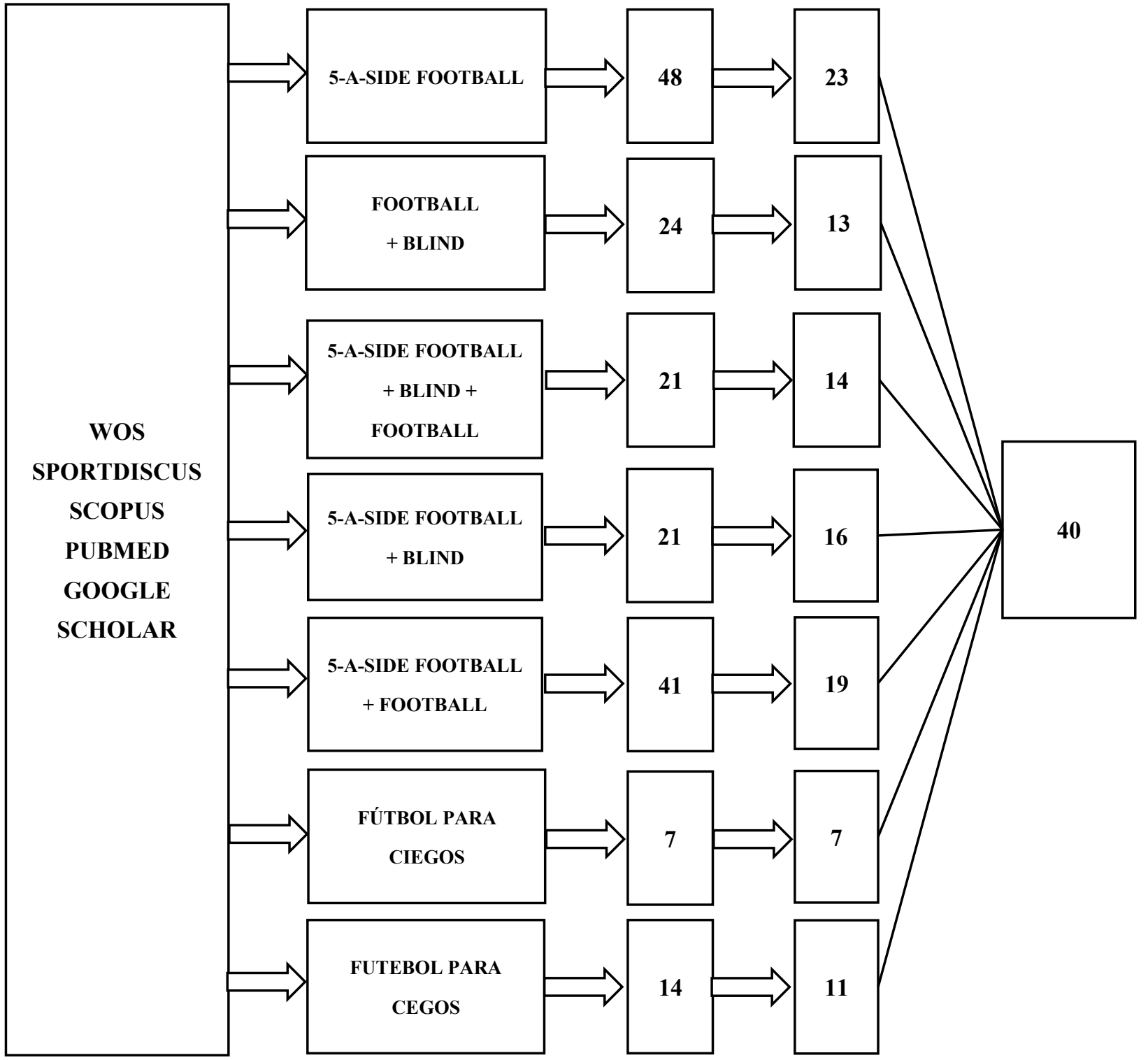

Figure 2. Number of documents found from the database

\section{Access to documents}

Full texts are not available in some of the databases used to conduct the literature search. Therefore, in order to gain access to as many original studies as possible, the electronic library of the University of Extremadura was used, as well as other web sites and search engines. 


\section{Information processing}

The 40 documents selected were saved in EndNote, a software tool for managing references. This kind of software is nowadays essential to handle and manage information (Benito et al., 2007). The type of document, keywords, abstract, aims of the study, etc. were analyzed in each study. A set of terms according to the topic of the study was assigned to those texts, which did not contain keywords. Initially, a total of $n=153$ keywords were found in the documents selected. After checking for keywords with the same meaning, the database was restructured, the keywords were grouped in families and the statistical analysis was conducted again $(n=16)$. The statistical package SPSS 21.0 was used to perform the statistical analysis. A descriptive and exploratory analysis was conducted to calculate the means and standard deviations of the keywords of the different documents. The word grouping process was completed twice. The following examples show the grouping process:

$$
\begin{gathered}
\text { Musical education }+ \text { Physical education }+ \text { Special education }=\text { Education } \\
\text { Strategy }+ \text { Paralympic training }+ \text { Periodization }=\text { Training }
\end{gathered}
$$

The keywords related to 5-a-side football for individuals with visual impairments are represented in Figure 3. Finally, the non-duplicate documents were classified by topic according to the Directory of Sport Science (Borms, 2008).

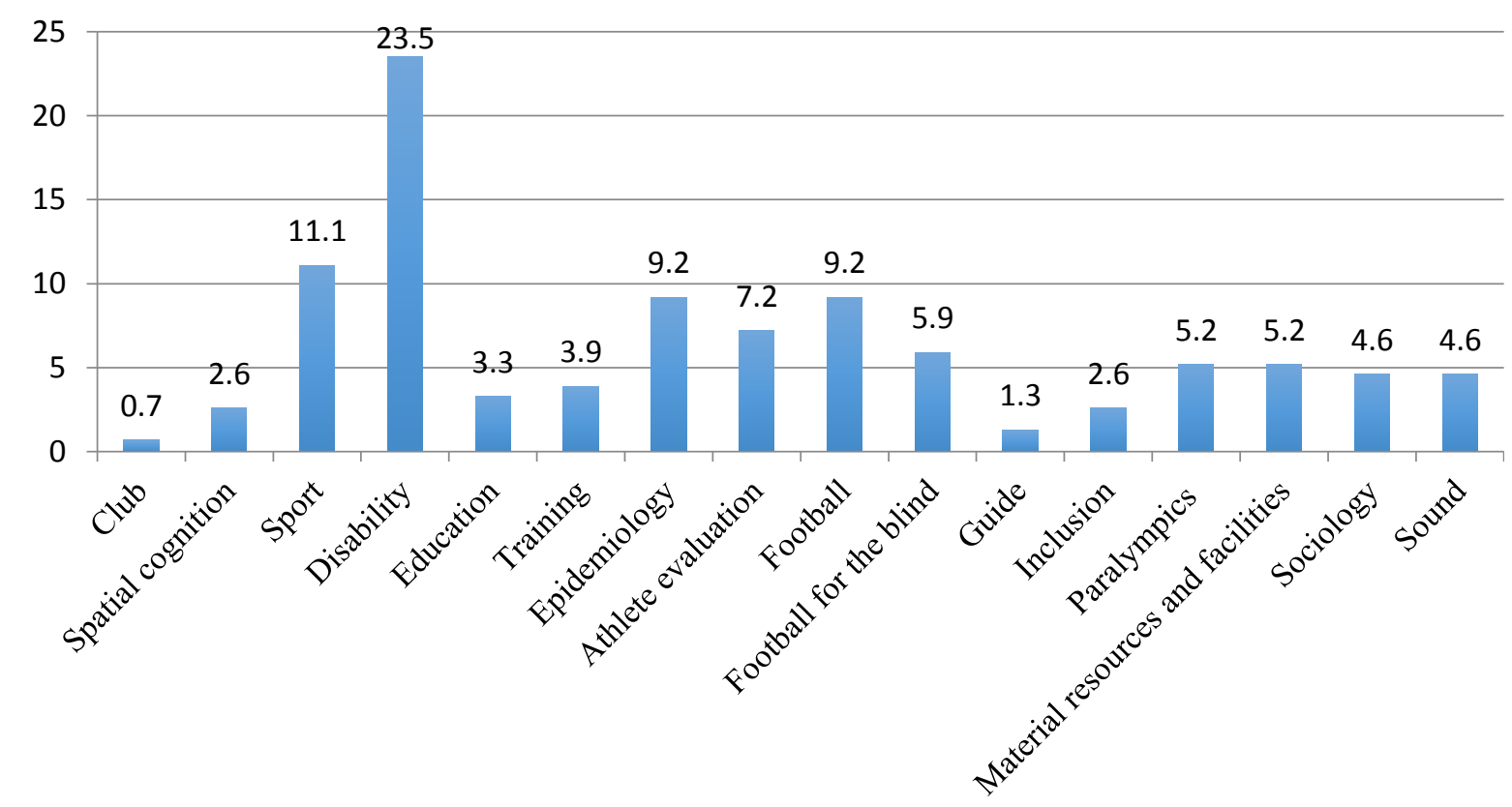

Figure 3. Most important keywords related to 5-a-side football for individuals with visual impairments

\section{Results}

Results are presented in the order in which the literature review was conducted. The document selection process is shown in Figure 2. The sample consisted of different types of documents $(n=40)$. Duplicate studies and those, which did not comply with the inclusion criteria, were excluded. Over half $(n=24)$ of the selected studies are written in English, 12 in Portuguese and 4 in Spanish. The majority $(n=29)$ documents are available in full-text version, whereas only an abstract is available for the rest of them. Subsequently, the selected documents were classified according to the topics included in the Directory of Sport Science (Borms, 2008). The documents were divided into 11 research disciplines (Figure 4). The following disciplines were excluded: Sports Law, Sport Philosophy, Kinanthropometry, Sport and Leisure Facilities, Sport Pedagogy and Sport and Exercise Psychology. Some of the documents included in the sample may belong to more than one discipline. The main characteristics of the documents concerning 5 -a-side football for individuals with visual impairments 
are presented in Appendix A following the criteria defined in the method. They are listed in chronological order.

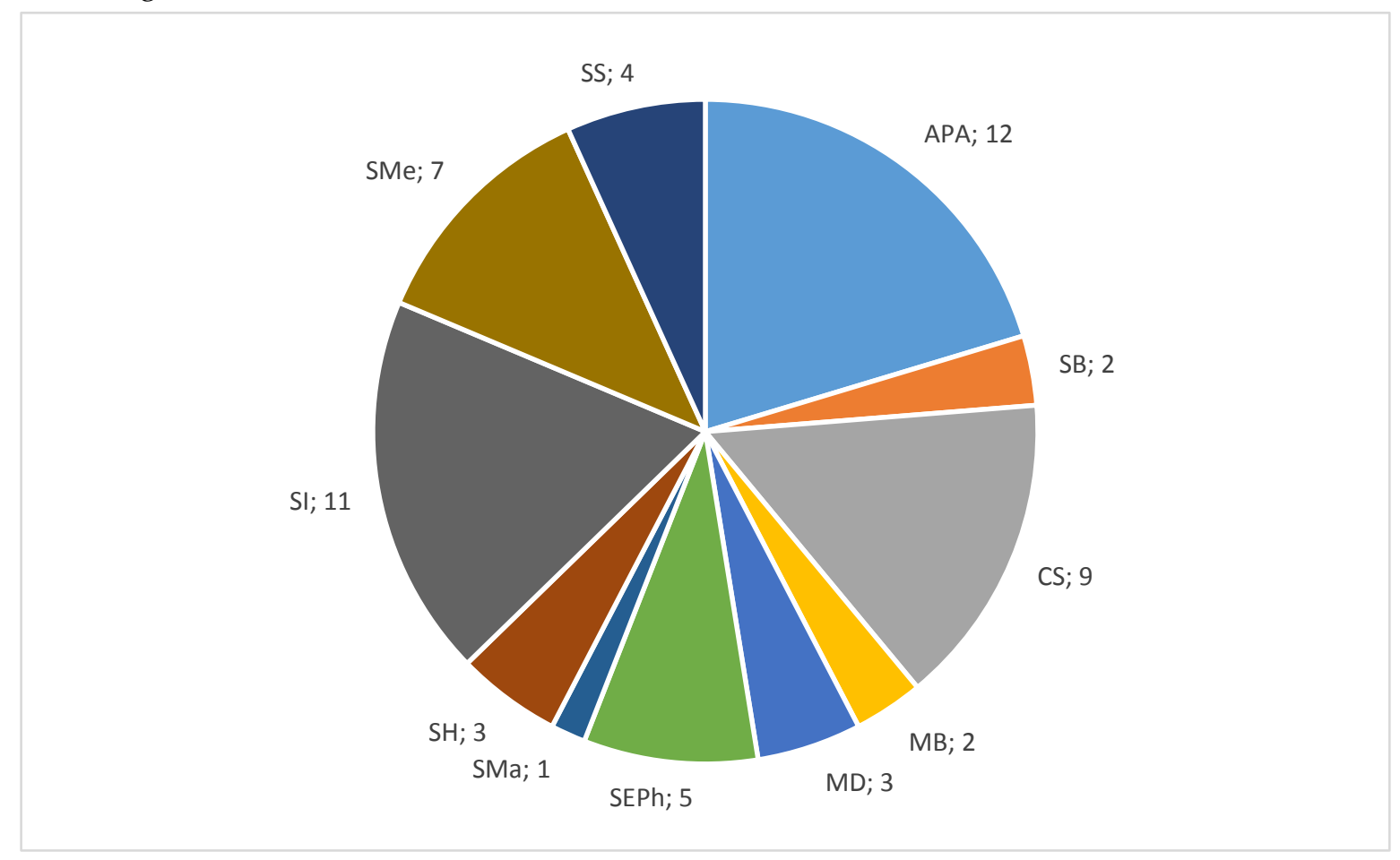

Figure 4. Document classification according to the Sport Science disciplines. APA Adapted Physical Activity Science, SB Sport Biomechanics, CS Coaching Science, MB Motor Behavior, MD Motor Development, Motor Control and Motor Learning, SEPh Sport and Exercise Physiology, SMa Sport Management, SH Sport History, SI Sport Information, SMe Sport Medicine, SS Sport Sociology

\section{Discussion}

The study aims were to conduct a new literature review which updates the state of the art in 5a-side football for individuals with visual impairments, following the methodological processes described in the literature (Ato et al., 2013; De Moura et al., 2015). It identifies and classifies the most relevant information regarding 5-a-side football, and it will be useful for the future bibliographic reviews. To develop a systematical review, the analysis and selection of keywords is important, because they allow to obtain an optimum number of documents related to the subject of the study. In the literature related with 5 -a-side football, the word disability is the most frequent $(n=23.5)$, followed by football $(n=9.2)$ and epidemiology $(n=9.2)$. The least mentioned words in the selected texts are: inclusion $(n=2,6)$, spatial cognition $(n=2,6)$, Guide $(n=1,3)$ and club $(n=0,7)$. A summary of the documents selected is presented below, and their contributions are classified according to the sport science disciplines.

\section{Adapted Physical Activity}

Twelve documents related to the APA discipline have been selected. 5-a-side football is presented as an instrument to prevent depression, obsessions and daily-life problems people with visual impairments, which provides countless benefits (Abolfotouh \& Telmesani, 1993; CIEPDV, 2005). 5-a-side football allows for development of positive attitudes towards orientation, mobility and daily-life autonomy. It is a collective and integrative sport (Abogado, 2009; Kopřivová \& Gil, 2013).

5-a-side football has the aim to cope with individuals with visual impairments' characteristics (Matsui, 2007). The specific adaptations are: the ball, the facilities (outdoors), the field dimensions, the team formation, the sides of the field, the mandatory use of an eye mask in order to make light perception equal for all, and the playing time (Abogado, 2009; Webborn \& Van de Vliet, 2012). 
Furthermore, it is important for the players to know all these adaptations (Matsui, 2007). Therefore, it is recommended that they check the facilities with a sighted person prior to the game, in order to collect information about the place and to prevent potential injuries (Koprivová \& Gil, 2013).

Nonetheless, not all people with visual impairments are able to experience football practice. There are restrictions to access initiation football (Macbeth, 2009). This is due to the lack of social inclusion actions. The education systems, and especially physical education teachers, have the resources to create inclusive actions (Miglinas, 2013). The practice of adapted sports in physical education classes may facilitate the integration process of people with disabilities at school or in daily life (Armella et al., 2013). Likewise, the broadcasting of adapted sports in the media offers the audience an opportunity to better understand and know sports for the disabled as well as the athletes' experiences (De Haan, Faull \& Kohe, 2014). Consequently, physical education classes and sport events for people with disabilities are unique sport environments to promote relationships among athletes, students and/or spectators. Besides, Paralympic sport has experienced an exponential participation increase since the first Olympic Games in London in 1948 (Webborn \& Emery, 2014). This change indicates that people progressively understand adapted sports.

\section{Sport Biomechanics}

There are two patents with the aim to improve 5-a-side football for the blind, related namely to the ball and the sound (Guo, 2008; Saidi, 2007). They have the purpose to make it easier for people with visual impairments to play football without any external aid and only trusting their high auditory acuity. These devices allow for development of systems, which improve the results of training and health in studies concerning physical activity and sport.

\section{Coaching Science}

This discipline comprehends the generated knowledge concerning sport performance, with the purpose of optimizing the learning, training and competition processes. The interaction of this scientific knowledge and its application on the training and competition processes constitute the specific body of knowledge of coaching science (Schaefer \& Wertheim, 2008). Nine studies related to this discipline were selected. The first documents (CIEPDV, 2005; Matsui, 2007) focus on the need of having an official ball or making creative adaptations to it. The main aspect to work on during training is spatial orientation (individual and team orientation), since this is what enables blind players to move (Campos, 2000). Training exercises must be progressive (Campos et al., 2013; Matsui, 2007). Progressive training where the tone of voice used to provide individuals with visual impairments with technical-tactical aspects is of paramount importance. Morato (2007) explains that attacking aspects must be trained more often because teams use pre-established movements and they organize depending on the ball movement. Thus, the following contents must be trained: balance, spatial orientation and psychomotor behavior, as well as learning about the game at both attacking and defending levels (Farias et al., 2008; Morato et al., 2011b). Likewise, it is important to work on the communication among all team members to know the location of the moving references (players), and to understand the characteristics of the team mates and opponents (Zare et al., 2014). Campos et al. (2014) suggest using training sessions to analyze the players' VO2 max and to examine their performance. Hence, these improvements and studies allow for design and planning of teaching and training programs, which are more appropriate for people with visual impairments.

\section{Motor Behavior}

This review contains two studies concerning Motor Behavior. These documents facilitate sport practice for the blind by supporting athletes and coaches with relevant information. They analyze the movement execution, learning and control. Velten, Bläsing, Portes, Hermann \& Schack (2014) and Velten, Ugrinowitsch, Portes, Hermann \& Bläsing (2016) analyze the mental representation of sound directions in blind footballers, with the aim to help players orient themselves in the playing field. Thus, they give the coach the possibility of doing more and more varied exercises and games. 


\section{Motor Development, Motor Control and Motor Learning}

Within the discipline of Motor Development, Motor Control and Motor Learning, the articles $(n=3)$ concern devices which help improve the practice and development of 5-a-side football. A special ball is used to learn about the different motor patterns of the athletes (Velten et al., 2014; Velten et al., 2016). The sound of the ball helps the players orient themselves. Zare et al. (2014) apply new methods to help people with visual impairments play football in a more efficient and safe manner. To do so, they create 3D sound with the purpose to represent the objects in the field in real time. Therefore, the main aim of these studies is to help people with visual impairments detect the location of moving objects, helping them in their daily lives as well.

\section{Sport and Exercise Physiology}

There are five manuscripts concerning direct applications of health and sport performance knowledge. A few of them contribute to injury prevention, training and rehabilitation of 5-a-side football players (Campos et al., 2015, Webborn \& Van de Vliet, 2012). Other authors focus on analyzing the players' physical condition, body composition and somatotype profile (Campos et al., 2014, Campos et al., 2013, Gorla et al., 2017). The results of the different tests may be used as reference parameters. These studies contribute to the prescription of future training programs. The different studies present the players' characteristics and profiles, which are essential for the coaches to compare and improve players' training.

\section{Sport Management}

Only one document is related to the topic of Sport Management. Rodríguez (2014) presents a descriptive report containing the general guidelines of an architectural project for the Centro de Entrenamiento Paralímpico (Paralympic training center). The design is conceived for people with different capacities and to promote inclusive programs, which lead to social integration, regardless of the physical and mental capacities.

\section{Sport History}

Informational articles are predominant in this discipline ( $n=3)$. Campos (2000) and Matsui (2007) introduce the sport modality and the main systems of play. Brazil is the most important country in this modality due to its football tradition. Spain, with three European Championship titles, is the exception (Campos, 2000). The IBSA World Championships and the Paralympic Games constitute the most important competitions. A bibliographic review on this topic may be found in the literature (De Moura et al., 2015). In general, the studies included in this review focus on the historical context, technical-tactical aspects and injuries. It is, however, a limited review, regarding the number of documents included. Constructive criticism of other authors' work allows scientific knowledge to progress.

\section{Sport Information}

The documents $(n=11)$ included in the discipline of Sport Information concern a large variety of topics. A few articles provide incorrect information about 5-a-side football and 5-a-side football for the blind due to the similarity of the playing rules (Campos, 2000; CIEPDV, 2005). For this reason, coaches, guides and players must know the sport modality and its rules. Kopřivová \& Gil (2013) describe the development of 5-a-side football for people with visual impairments, the position of players and their own experiences (Nascimento, 2014), the people involved and the competitions (Macbeth, 2009; Macbeth \& Magee, 2006; Masto \& Zaehle, 2008). The guide is the person who transmits the playing intensity in order to achieve a better solution, generates trust in the player and builds a code with him/her. It is, undoubtedly, one of the most important roles within this adapted sport modality (Suarez, 2014). A trained and specialized guide is crucial to achieve success in 5-a-side football for individuals with visual impairments. 
Twaddle (2014) sheds light on the implementation of a workshop about 5-a-side football and on how it may facilitate the inclusion of the deaf or individuals with visual impairments. Levandoski (2015) comments on the book by Souza, Campos \& Gorla (2014) with the aim to spread the experience of this sport and, therefore, to contribute to the development and growth of 5-a-side football on school level. Finally, De Moura et al. (2015) use two languages in their literature review about the present research topic. Despite them having used English and Portuguese, it seems necessary to use one more language to complete the study. By doing so, more tools to search for related information will be available.

\section{Sport Medicine}

The documents included concern mostly injuries and illnesses of Paralympic athletes in general (Fagher \& Lexell, 2014; Van de Vliet, 2014; Webborn \& Emery, 2014; Webborn \& Van de Vliet, 2012) and, more specifically, of 5-a-side football players (Magno et al., 2013; Webborn et al., 2015; Willick et al., 2013). In these studies, 5-a-side football for individuals with visual impairments is referred to as the adapted sport with the highest injury rate. It constitutes a dangerous sport modality for the players, as long as they do not wear the appropriate protections. It would be interesting to conduct a deeper analysis about how injuries may be prevented. Knee and ankle injuries were the most prevalent ones during the 2012 Paralympic Games (Webborn et al., 2015). Consequently, unfair play needs to be evaluated and, in light of this information, prevention and intervention strategies need to be implemented in future sport events.

\section{Sport Sociology}

The studies within the discipline of Sport Sociology present a large variety of topics $(n=4)$ : analysis of competition audience (De Haan et al., 2014), analysis of the life and success of players like Silvio Velo (Varsky, 2012), research on the creation of the football phenomenon in Brazil (Morato et al., 2011a) and, lastly, description of the context and people involved in the development of 5-a-side football for the blind in Brazil (Morato et al., 2011c). In general, all these documents include a social analysis of people related either directly or indirectly to 5-a-side football.

\section{Conclusions}

The literature review process has permitted the identification of different kinds of documents, which address the study of 5-a-side football for individuals with visual impairments. There are journal articles, academic projects, congress and scientific meeting publications, books, patent documents and book chapters which indicate that this is an emerging research topic. Therefore, it seems necessary to further study this discipline.

The literature review has led to classification of the documents into eleven sport science disciplines. Within each of them, the most relevant contributions to 5-a-side football for the blind have been summarized. This summary will be useful for researchers. The present study significantly improves the previous bibliographic review of 5 -a-side football for the blind, which seems incomplete. The biggest limitation of the present study is the scarce scientific literature regarding 5a-side football for individuals with visual impairments, in contrast with a large number of informational articles.

\section{Perspectives}

In the present review of the literature, an approximation to 5-a-side football has been made, with the purpose of describing and defining the main characteristics of a sport modality adapted for individuals with visual impairment. However, it is necessary to continue investigating to know in depth the 5-a-side football with future studies that increase the scientific knowledge of 5-a-side football. It would be interesting to analyze the injuries of the players, to know the different competitive levels, and even to inquire about the design of training tasks, as well as to know the sports performance indicators in 5-a-side football. 


\section{Author affiliations:}

1 Research Group in Optimization of Training and Performance Sports. Faculty of Sport Sciences. University of Extremadura, Spain.martingamonales@unex.es suliwan@unex.es / jesus.munoz@uautonoma.cl fleon@unex.es / kiko.leon@uautonoma.cl sibanez@unex.es.

2 Universidad Autónoma de Chile, Chile. jesus.munoz@uautonoma.cl / kiko.leon@uautonoma.cl

* Correspondence: martingamonales@unex.es

Author Contributions: José M. Gamonales: Prepared the full document: introduction, method, discussion and conclusion. Jesús Muñoz-Jiménez: review the method and develop the statistical process, as well as revising the final document. Kiko León-Guzmán: collaborated in the review of the document, specifically in the introduction, method and discussion. Sergio J. Ibáñez: develop the method, and analysis of the documents. In addition, he reviewed the final document.

Funding: This work has been partially subsidized by the Assistance to Research Groups (GR15122) of the Junta de Extremadura (Ministry of Employment and Infrastructures); With the contribution of the European Union through the European Funds of Regional Development (FEDER).

Acknowledgments: The study developed within the Group to Optimization of Training and Performance Sports of Faculty of Physical Activity and Sport Sciences (University of Extremadura, Spain).

Conflicts of Interest: The authors declare no conflict of interest.

\section{References}

Abogado, J. (2009). La integración del deporte adaptado como fuente de conflicto normativo. [Integration of adapted sport as a source of normative conflict]. Anuario Andaluz, 9, 159-182.

Abolfotouh, M., \& Telmesani, A. (1993). A study of some psycho-social characteristics of blind and deaf male students in Abha City, Asir Region, Saudi. Public Health, 107(4), 261-269.

Armella, J. C., Debórtoli, R., \& Pallero, P. (2013). Juntos buscamos el camino [Together we seek the way]. Paper presented at the $10^{\circ}$ Congreso Argentino de Educación Física y Ciencias, 9 to 13 September, 2013. La Plata (Argentina). Ato, M., López, J. J., \& Benavente, A. (2013). Un sistema de clasificación de los diseños de investigación en psicología [A classification system of research designs in psychology]. Anales de Psicología, 29(3), 1038-1059. doi:10.6018/analesps.29.3.178511Ato, M., López, J. J., \& Benavente, A. (2013). Un sistema de clasificación de los diseños de investigación en psicología. Anales de Psicología, 29(3), 10381059. doi:10.6018/analesps.29.3.178511

Benito, P. J., Díaz, V., Calderón, M. J., Peinado, A. B., Martín, C., Álvarez, M., Morencos, E., \& Pérez-Tejero, J. 388 (2007). La revisión bibliográfica sistemática en fisiología del ejercicio: recomendaciones prácticas [Literature review in exercise Physiology: practical recommendations]. International Journal of Sport Science, 3(6), 1-11.

Borms, J. (2008). Directory of sport science: A journey through time: the changing face of ICSSPE. Berlin: Champaign, IL; Human Kinetics.

Campos, C. (2000). Blind football. In Gonzalez, X. Minute book Scientific Congress (5th) Paralympic Games. International Paralympic Committe, Sydney, Australia.

Campos, L. F., Borin, J. P., Santos, L. G., Souza, T. M., Paranhos, V. M., Tanhoffer, R. A., Luarte, C., \& Gorla, J. I. (2015). Avaliação isocinética em atletas da seleção brasileira de futebol de 5 [Isokinetic evaluation of Brazilian 5-a-side team]. Revista Brasileira de Medicina do Esporte, 21(3), 220-223.

Campos, L. F., Borin, J. P., Nightingale, T., Silva, A. A., Araújo, P. F., \& Gorla, J. I. (2014). Alterations of cardiorespiratory and motor profile of Paralympic 5-a-side football athletes during 14-week in-season training. International Journal of Sports Science, 4(6A), 85-90. doi:10.5923/s.sports.201401.12

Campos, L. F., Borin, J. P., Santos, L. G., Souza, T. M., Paranhos, V. M., Tanhoffer, R. A., Luarte, C., \& Gorla, J. I.(2015). Avaliação isocinética em atletas da seleção brasileira de futebol de 5 [Isokinetic evaluation of Brazilian 5-a-side team]. Revista Brasileira de Medicina do Esporte, 21(3), 220-223.

Campos, L. F., De Athayde, A., Dos Santos, L., Costa, L. T., Montagner, P., Borin, J., De Araújo, P., \& Gorla, J. (2013). Effects of training in physical fitness and body composition of the Brazilian 5-a-side football team. Revista Andaluza de Medicina del Deporte, 6(3), 91-95.

CIEPDV - Consejo Internacional para la Educación de las Personas con Discapacidad Visual (2005). Deportes y recreación para personas con discapacidad visual: Jugando el partido de tu vida [Sports and recreation for people with visual disabilities: Playing the game of your life]. El Educador, 18(1), 1-69.

De Haan, D., Faull, A., \& Kohe, G. Z. (2014). Celebrating the social in soccer: spectators' experiences of the forgotten (Blind) Football World Cup. Soccer and Society, 15(4), 578-595. doi:10.1080/14660970.2013.828596 
De Moura, M. A., Calsavara, C. Q., Da Silva, B. V. C., Da Mota, G. R., \& Moreira, H. F. (2015). Futebol de cinco para deficientes visuais [Football 5-a-side for visually impaired]. Revista Brasileira de Futsal e Futebol, $7(24), 231-236$.

DePauw, K., \& Doll-Tepper, G. (2000). Toward progressive inclusion and acceptance: Myth or reality? The inclusion debate and bandwagon discourse. Adapted Physical Activity Quarterly, 17(2), 135-143. doi:10.1123/apaq.17.2.135

DePauw, K., \& Sherrill, C. (1994). Adapted physical activity: present and future. Physical Education Review, 17(1), 6-13.

Doll-Tepper, G., \& DePauw, K. (1996). Theory and practice of adapted physical activity: Research perspectives. Sport Science Review, 5(1), 1-11

Fagher, K., \& Lexell, J. (2014). Sports-related injuries in athletes with disabilities. Scandinavian Journal of Medicine and Science in Sports, 24(5), 320-331. doi:10.1111/sms.12175

Farias, A., Oliveira, C., Gonçalves, R., \& Sória, R. (2008). Desenvolvimento da aprendizagem do futebol para portadores de deficiencia visual [Development of football learning for people with visual impairment]. Revista Mackenzie de Educação Física e Esporte, 7(3), 17-25

Gamonales, J. M. (2016). Fútbol para personas ciegas y con deficiencia visual: "Un mundo sin descubrir" [Football for blind and visually impaired people: "An undiscovered world"]. In Gallardo, D., \& Urraco, M. (2016). Catalog of Young Research in Extremadura, Edition 2015 (chap. 29). Cáceres: Servicio de Publicaciones de la Universidad de Extremadura

Gamonales, J. M., León, K., Muñoz, J., González-Espinosa, S., \& Ibáñez, S. J. (2018). Validación del IOLF5C para la eficacia del lanzamiento en fútbol para ciegos [Validation of the IOLF5C instrument for the Efficacy of shooting on goal in football for the blind]. Revista Internacional de Medicina y Ciencias del Deporte, 18(70), 361-381. doi: 10.15366.rimcafd2018.70.010

Giagazoglou, P., Katis, A., Kellis, E., \& Natsikas, C. (2011). Differences in soccer kick kinematics between blind players and controls. Adapted Physical Activity Quarterly, 28(3), 251-266. doi: 10.1123/apaq.28.3.251

Gorla, J. I., de Athayde Costa, A., de Campos, L. F. C. C., dos Santos, C. F., de Almeida, J. J. G., Duarte, E., \& Queiroga, M. R. (2017). Composição corporal e perfil somatotípico de atletas da seleção brasileira de futebol de 5 [Body composition and somatotype of athletes of Brazilian 5-a-side football team]. Revista Brasileira de Ciências do Esporte, 39(1), 79-84. doi:10.1016/j.rbce.2015.12.016

Guo, D. (2008). Balls for use in blind for exercise and amusement, comprises small bells fixed inside ball to ring 434 when ball is in motion to find out ball by listening to ring of small bells. US20070141541. China: Google Patents.

Gutiérrez, M., \& Oña, A. (2005). Metodología en las ciencias del deporte [Methodology of sports science.]. Madrid: Síntesis

Hernández, J. (2005). Análisis de las estructuras del juego deportivo [Analysis of sports game structures] (3 ed.). Zaragoza: INDE

IBSA-International Blind Sports Federation (2017, November 7). Fútbol - Información general. Consultado en http://www.ibsasport.org/sports/football/

Kopřivová, P., \& Gil, A. (2013). Management of Paralympics Games: Problems and perspectives Bachelor Thesis. MASARYK University. Faculty of Sport Studies. Department of Social Sciences in Sport and Department of Health Promotion, República Checa.

Levandoski, G. (2015). Futebol para deficientes visuais: Football 5-a-side [Football for visual impairment people: Football 5-a-side]. Brazilian Journal of Special Education, 21(1), 177-178. doi:10.1590/S141365382115000100012

Macbeth, J. (2009). Restrictions of activity in partially sighted football: experiences of grassroots players. Leisure Studies, 28(4), 455-467. doi:10.1080/02614360903071696

Macbeth, J., \& Magee, J. (2006). 'Captain England? Maybe one day I will': Career paths of elite partially sighted footballers. Sport in Society, 9(3), 444-462. doi:10.1080/17430430600673464

Magno, M. P., Morato, M. P., Bilzon, J. L., \& Duarte, E. (2013). Sports injuries in Brazilian blind footballers. International journal of sports medicine, 34(3), 239-243. doi:10.1055/s-0032-1316358

Masto, F., \& Zaehle, T. (2008). Spatial reference frames used in mental imagery tasks (Soccer for visually impaired persons). In P. Press (Ed.), Blindness and brain plasticity in navigation and object perception (Vol. 1, pp. 239-258). New York: Erlbaum.

Matsui, R. (2007). Iํ Jogoa Escolares Brasileiros da Confederação Brasileira de Desportos para Cegos: Um estudo de caso (Programa de Pós-Graduação em Educação Física) [Io Games for Brazilian Schoolchildren of the Brazilian Confederation of Sports for Blind people: A case study (Post-Graduation Program in Physical Education)]. Universidade Estadual de Campinas. Faculdade de Educação Física, Brasil 
Mendoza, N. (2007). Tendencias de Investigación en deporte y actividad física adaptada en el ámbito nacional [Research trends in sport and adapted physical activity at the national scene]. Paper presented at the II Conferencia Internacional sobre Deporte Adaptado. Faculty of Sports Sciences of the UCLM. Málaga.

Miglinas, L. (2013). O esporte adaptado como conteúdo nas aulas de Educação Física (Programa de Pósgraduação em Educação Física) [Adapted sport as a content in the Physical Education lessons (Postgraduate Program in Physical Education)]. Universidade Federal do Espírito Santo. Centro de Educação Física e Desporto, Brasil

Morato, M. P. (2007). Futebol para cegos (futebol de cinco) no Brasil: leitura do jogo e estratégias tático-técnicas. Dissertação (Mestrado em Educação Física) [Football for blind people (soccer of five) in Brazil: reading the game and tactical-technical strategies. Dissertation (Master's Degree in Physical Education)]. Faculdade de Educação Física, Universidade Estadual de Campinas, Brasil.

Morato, M. P., Giglio, S., \& Gomes, M. (2011a). A construção do ídolo no fenômeno futebol [The construction of the idol in the football phenomenon]. Motriz: Revista de Educação Física, 17, 1-10. doi: 10.5016/19806574.2011v1n1p1.

Morato, M. P., Gomes, M., Duarte, E., \& De Almeida, J. J. (2011b). A leitura de jogo no futebol para cegos [Football for the blind game analysis]. Movimento: Revista de Educação Física Da UFRGS, 17(3), 97-114. doi:10.22456/1982-8918.17261

Morato, M. P., Gomes, M., Scaglia, A. J., \& De Almeida, J. J. (2011c). A mediação cultural no futebol para cegos [Cultural mediation in football for the blind]. Movimento: Revista de Educação Física Da UFRGS, 17(4), 4563. doi:10.22456/1982-8918.17256

Nascimento, M. (2014). Relato de experiência: a prática do futebol de 5 (futsal) para pessoas com deficiência visuais [Experience report: the soccer practice of 5 (football) for the people with visual impairment]. (Trabalho de Conclusão de Curso - Graduação em Educação Física). Universidade Estadual da Paraíba, Brasil.

Pérez-Tejero, J. (2009). La investigación en actividades físicas y deportes adaptados: un camino aún por recorrer [Research on adapted physical activities and sports: a path still to be traveled]. Revista Internacional de Ciencias del Deporte, 5(16), 1-3.

Pérez-Tejero, J., Reina-Vaíllo, R., \& Sanz , D. (2012). La actividad física adaptada para personas con discapacidad en España: perspectivas científicas y de aplicación actual [Adapted Physical Activity for people with disability in Spain: scientific perspectives and current issuess]. Cultura, Ciencia y Deporte, 7(21), 213-224. doi:10.12800/ccd.v7i21.86

Reid, G., \& Prupas, A. (1998). A documentary analysis of research priorities in disability sport. Adapted Physical Activity Quarterly, 15(2), 168-178. doi:10.1123/apaq.15.2.168

Reynolds, R. P. (1984). Research in adapted physical activity: Some reflections and modest proposals. Adapted Physical Activity Quarterly, 1(4), 263-266. doi:10.1123/apaq.1.4.263

Rodríguez, M. (2014). Centro de entrenamiento paralímpico [Paralympic training center]. Universidad de Chile. Facultad de Arquitectura y Urbanismo. Escuela de Arquitectura, 1-85.

Saidi, N. L. (2007). Sound guided football/basketball game for individuals with visual impairments US20070238557 A1. Los Ángeles: Google Patents.

Schaefer, U., \& Wertheim, M. (2008). Coaching science. In J. Borms (Ed.), Directory of Sport Science: A Journey Through Time: the Changing Face of ICSSPE (5th ed., pp. 119-136). Champaign, IL; Human Kinetics.

Sherrill, C., \& O'Connor, J. (1999). Guidelines for improving adapted physical activity research. Adapted Physical Activity Quarterly, 16(1), 1-8. doi:10.1123/apaq.16.1.1

Souza, R., Campos, L., \& Gorla, J. (2014). Futebol de 5: fundamentos e diretrizes [Football 5: fundamentals and guindelines]. São Paulo: Atheneu

Suarez, G. (2014). Importancia del rol del guía o llamador en el fútbol para ciegos. Revista electrónica de Ciencias Aplicadas al Deporte, 7(25), 1-6.

Thomas, J.R., Silverman, S. J., \& Nelson, J.K. (2015). Research methods in physical activity (7ª Ed). Campaign, IL: Human Kinetics.

Twaddle, A. (2014). Football 5-a-side workshop for students who are blind. COAHPERD Journal, 40(3), 5.

Van de Vliet, P. (2014). The importance of injury and illness surveillance in paralympic athletes. British Journal of Sports Medicine, 48(7), 669-669. doi:10.1136/bjsports-2014-093494.292

Varsky, A. (2012). The blind Maradona. FIFA World, (27), 55-59.

Velten, M. C., Bläsing, B., Portes, L., Hermann, T., \& Schack, T. (2014). Cognitive representation of auditory space in blind football experts. Psychology of Sport and Exercise, 15(5), 441-445. doi:10.1016/j.psychsport.2014.04.010

Velten, M. C., Ugrinowitsch, H., Portes, L. L., Hermann, T., \& Bläsing, B. (2016). Auditory spatial concepts in blind football experts. Psychology of Sport and Exercise, 22, 218-228. doi:10.1016/j.psychsport.2015.08.010 
Webborn, N., \& Emery, C. (2014). Descriptive epidemiology of Paralympic sports injuries. Paralympic Sport Medicine and Science, 6(8), 18-22. doi:10.1016/j.pmrj.2014.06.003

Webborn, N., \& Van de Vliet, P. (2012). Paralympic medicine. The Lancet, 380(9836), 65-71. doi:10.1016/S01406736(12)60831-9

Webborn, N., Cushman, D., Blauwet, C. A., Emery, C., Derman, W., Schwellnus, M., Stomphorst, M., De Vliet, P., \& Willick, S. E. (2015). The epidemiology of injuries in football at the London 2012 Paralympic Games. Scientific Journal of the American Academy of Physical Medicine and Rehabilitation, 8(6), 545-552. doi:10.1016/j.pmrj.2015.09.025

Willick, S. E., Webborn, N., Emery, C., Blauwet, C. A., Pit-Grosheide, P., Stomphorst, J., Marques, N., MartínezFerrer, J., Jordaan, E., Derman, W., \& Schwellnus, M. (2013). The epidemiology of injuries at the London 2012 Paralympic Games. British Journal of Sports Medicine, 47(7), 426-432. doi:10.1016/bjsports-2013-092374

Zare, A., McMullen, K., \& Gardner-McCune, C. (2014). Design of an accessible and portable system for soccer players with visual impairments. Paper presented at the Proceedings of the extended abstracts of the 32nd annual ACM conference on Human factors in computing systems. terms and conditions of the Creative Commons Attribution (CC BY) license (http://creativecommons.org/licenses/by/4.0/). 


\section{Appendix A}

Most relevant studies concerning 5-a-side football for individuals with visual impairments and characteristics.

\begin{tabular}{|c|c|c|c|c|}
\hline Author/s and year & Type & Disciplines & $\begin{array}{l}\text { Scientific } \\
\text { quality* }\end{array}$ & Keywords \\
\hline $\begin{array}{l}\text { Abolfotouh \& Telmesani } \\
\text { (1993) }\end{array}$ & JA & APA & Yes & $\begin{array}{l}\text { Disability, Epidemiology, } \\
\text { Sociology, Football }\end{array}$ \\
\hline Campos (2000) & JA & $\begin{array}{l}\mathrm{SH} \\
\mathrm{CS} \\
\mathrm{SI}\end{array}$ & No & $\begin{array}{l}\text { Disability, Football, Athlete } \\
\text { evaluation }\end{array}$ \\
\hline CIEPDV (2005) & B & $\begin{array}{c}\text { APA } \\
\text { CS } \\
\text { SI }\end{array}$ & No & Disability, Sport, Inclusion \\
\hline Macbeth \& Magee (2006) & JA & SI & No & $\begin{array}{l}\text { Football for the blind, } \\
\text { Disability, Material } \\
\text { resources and facilities, } \\
\text { Club }\end{array}$ \\
\hline Morato (2007) & $\mathrm{AP}$ & CS & Yes & $\begin{array}{c}\text { Disability, Football, Sport, } \\
\text { Education }\end{array}$ \\
\hline Matsui (2007) & $\mathrm{AP}$ & $\begin{array}{c}\mathrm{APA} \\
\mathrm{CS} \\
\mathrm{SH}\end{array}$ & No & $\begin{array}{l}\text { Disability, Paralympics, } \\
\text { Football for the blind }\end{array}$ \\
\hline
\end{tabular}

Saidi (2007)

Study which presents the psychosocial characteristics and daily-life problems of 152 male students of the Institute for the Blind and the Institute for the Deaf in Abha City (Saudi Arabia).

Informational article where an introduction about football 5-a-side for individuals with visual impairments is provided.

The International Blind Sports Federation is described. Furthermore, the different sports practiced by individuals with visual impairments are listed and their main characteristics are explained.

The development of 5-a-side football for people with visual impairment is described. The career paths of a group of partially sighted footballers selected to represent England at the Partially Sighted World Championships in 2004 are examined.

The study analyzes the specific characteristics of football for the blind: origin, people involved, team management and organization and technicaltactical strategies used by players.

Academic work which describes, analyzes, evaluates and documents the $1^{\text {st }}$ Brazilian School Games for youngsters with visual impairment, held by the Brazilian Blind Sports Confederation in Sao Paulo, from November 12 to 15, 2004.

Device which allows individuals with visual impairments to hear the ball. The football emits different tones depending on its position, making it easier to locate it. The blind player wears a special helmet which allows him/her to receive sound information and to play football without any external help, only trusting their high auditory acuity. 


\begin{tabular}{|c|c|c|c|c|c|}
\hline Guo (2008) & PD & SB & No & $\begin{array}{c}\text { Material resources and } \\
\text { facilities, Disability, Sound }\end{array}$ & $\begin{array}{l}\text { Document which reports a ball for the blind. It comprises small bells fixed } \\
\text { inside the ball. The biggest advantage of this model is that it may be used for } \\
\text { several exercises for the blind, including football. }\end{array}$ \\
\hline $\begin{array}{l}\text { Farias, Oliveira, } \\
\text { Gonçalves \& Sória (2008) }\end{array}$ & $\mathrm{JA}$ & CS & Yes & $\begin{array}{l}\text { Football for the blind, } \\
\text { Training }\end{array}$ & $\begin{array}{l}\text { The aims of this study were to analyze initiation } 5 \text {-a-side football for } \\
\text { individuals with visual impairments, focusing on the strategies applied to } \\
\text { teach them to play, and to compare the difficulties of the people with visual } \\
\text { impairments with those in the literature, regarding the following aspects: } \\
\text { spatial orientation and psychomotor behavior. }\end{array}$ \\
\hline Abogado (2009) & B & APA & No & $\begin{array}{l}\text { Sport, Disability, Inclusion, } \\
\text { Football for the blind }\end{array}$ & $\begin{array}{l}\text { Book in which the different integration processes in adapted sports and, } \\
\text { more specifically, in 5-a-side football for the blind, are reported. The main } \\
\text { adaptations of FIFA rules are explained. }\end{array}$ \\
\hline Macbeth (2009) & $\mathrm{JA}$ & $\begin{array}{l}\text { APA } \\
\text { SI }\end{array}$ & Yes & $\begin{array}{l}\text { Disability, Football, } \\
\text { Sociology, Sport }\end{array}$ & $\begin{array}{l}\text { Article which examines the restrictions experienced by British partially } \\
\text { sighted individuals when accessing to football at grassroots level. }\end{array}$ \\
\hline $\begin{array}{l}\text { Morato, Gomes, Duarte \& } \\
\text { De Almeida (2011b) }\end{array}$ & $\mathrm{JA}$ & CS & Yes & Football, Disability, Sport & $\begin{array}{l}\text { The aim of this study was to analyze and describe the players' strategy when } \\
\text { reading the game in football for visually impaired. Players and coaches were } \\
\text { interviewed. }\end{array}$ \\
\hline Morato et al. (2011c) & JA & SS & Yes & Football, Disability, Sport & $\begin{array}{l}\text { This paper aimed to describe and analyze the context and people responsible } \\
\text { for the development of football for the blind in Brazil. Players and coaches } \\
\text { were interviewed. }\end{array}$ \\
\hline $\begin{array}{l}\text { Webborn \& Van de Vliet } \\
\qquad(2012)\end{array}$ & JA & $\begin{array}{l}\text { APA } \\
\text { SPh } \\
\text { SMe }\end{array}$ & Yes & $\begin{array}{l}\text { Sport, Paralympic, } \\
\text { Epidemiology }\end{array}$ & $\begin{array}{l}\text { The article Paralympic medicine describes the health-care issues of the } \\
\text { approximately 4,500 athletes who gather every } 4 \text { years to compete in } 20 \\
\text { sports at the Summer Paralympic Games and in } 5 \text { sports at the Winter } \\
\text { Paralympic Games. }\end{array}$ \\
\hline Varsky (2012) & $\mathrm{JA}$ & SS & No & $\begin{array}{l}\text { Football, Disability, } \\
\text { Sociology }\end{array}$ & $\begin{array}{l}\text { This paper is focused on the life and success of the captain of the } \\
\text { Argentinian national blind football team, Silvio Velo. He was born blind }\end{array}$ \\
\hline
\end{tabular}




\begin{tabular}{|c|c|c|c|c|c|}
\hline & & & & & $\begin{array}{l}\text { after being infected with toxoplasmosis; he has passion for football and used } \\
\text { to play with his sighted friends. }\end{array}$ \\
\hline Campos et al. (2013) & JA & $\begin{array}{c}\mathrm{CS} \\
\mathrm{SPh}\end{array}$ & Yes & $\begin{array}{l}\text { Training, Paralympics, } \\
\text { Athlete evaluation, Sport }\end{array}$ & $\begin{array}{l}\text { Study which aimed to analyze the effect of } 16 \text { weeks of training on physical } \\
\text { condition and body composition parameters in athletes of the Brazilian 5-a- } \\
\text { side football team. }\end{array}$ \\
\hline $\begin{array}{l}\text { Armella, Debórtoli \& } \\
\text { Pallero (2013) }\end{array}$ & CSM & APA & Yes & $\begin{array}{l}\text { Education, Inclusion, } \\
\text { Sociology }\end{array}$ & $\begin{array}{l}\text { Analysis of the Project Integración Educativa (educational integration). } \\
\text { Initially, the group consisted of } 35 \text { teachers studying at the Instituto Superior } \\
\text { de Formación Docente y Técnica (high institute for teaching and technical } \\
\text { education) in Pehuajó and seven individuals with visual impairments. The } \\
\text { activity proposed the integration of visually impaired people into society, as } \\
\text { well as specific pedagogical practices for teachers. }\end{array}$ \\
\hline Kopřivová \& Gil (2013) & $\mathrm{AP}$ & $\begin{array}{l}\text { APA } \\
\text { SI }\end{array}$ & Yes & $\begin{array}{l}\text { Material resources and } \\
\text { facilities, Paralympics }\end{array}$ & $\begin{array}{l}\text { This work provides with information on the Paralympic Games, namely the } \\
\text { problems that athletes may find and their perspective. }\end{array}$ \\
\hline Miglinas (2013) & $\mathrm{AP}$ & APA & Yes & Sport, Education, Inclusion & $\begin{array}{l}\text { The aims of the study are: a) to describe and analyze the process of } \\
\text { systematization and transmission of adapted sports as teaching content in } \\
\text { physical education classes at school, and b) to identify and analyze to which } \\
\text { extent the practice of adapted sports in physical education classes can } \\
\text { facilitate the inclusion process. }\end{array}$ \\
\hline Magno et al. (2013) & JA & SMe & Yes & $\begin{array}{l}\text { Epidemiology, Paralympic, } \\
\text { Disability, Football }\end{array}$ & $\begin{array}{l}\text { The purpose of this study was to assess the characteristics and prevalence of } \\
\text { sports-related injuries in athletes with visual impairments of the Brazilian 5- } \\
\text { a-side football team. }\end{array}$ \\
\hline Willick et al. (2013) & JA & $\mathrm{SMe}$ & Yes & $\begin{array}{l}\text { Epidemiology, Injuries, } \\
\text { Paralympics }\end{array}$ & $\begin{array}{l}\text { The aim of this prospective study was to characterize the incidence and } \\
\text { nature of injuries during the London } 2012 \text { Paralympic Games. }\end{array}$ \\
\hline Campos et al. (2014) & JA & $\mathrm{CS}$ & Yes & $\begin{array}{l}\text { Sports, Training, Disability, } \\
\text { Athlete evaluation }\end{array}$ & $\begin{array}{l}\text { The aims of this study were: a) to observe the cardiorespiratory and motor } \\
\text { profile changes of blind 5-a-side footballers from the Brazilian Paralympic } \\
\text { team before and after } 14 \text { weeks of training, and b) to compare these results } \\
\text { with other studies concerning futsal players of different levels to determine } \\
\text { the differences in cardiorespiratory and motor profiles among similar } \\
\text { modalities. }\end{array}$ \\
\hline $\begin{array}{l}\text { De Haan, Faull \& Kohe } \\
\text { (2014) }\end{array}$ & JA & $\begin{array}{l}\text { APA } \\
\text { SS }\end{array}$ & Yes & $\begin{array}{l}\text { Football, Disability, } \\
\text { Material resources and } \\
\text { facilities }\end{array}$ & $\begin{array}{l}\text { Article, which analyzes the } 2010 \text { World Blind Football Championships } \\
\text { (WBFC) and its audience. Structured interviews, orientated to the perception } \\
\text { of disability/ sport for the disabled, were conducted with } 285 \text { spectators. }\end{array}$ \\
\hline
\end{tabular}




\begin{tabular}{|c|c|c|c|c|c|}
\hline Rodríguez (2014) & B & SMa & No & $\begin{array}{l}\text { Material resources and } \\
\text { facilities Disability, Training }\end{array}$ & $\begin{array}{l}\text { Descriptive report containing the general guidelines of the architectural } \\
\text { project for the Centro de Entrenamiento Paralímpico (Paralympic training } \\
\text { centre). The facilities and sports that may be practiced in them are described. }\end{array}$ \\
\hline $\begin{array}{l}\text { Velten, Bläsing, Portes, } \\
\text { Hermann \& Schack (2014) }\end{array}$ & JA & $\begin{array}{l}\mathrm{MB} \\
\mathrm{MD}\end{array}$ & Yes & $\begin{array}{l}\text { Football for the blind, } \\
\text { Disability, Sound, Spatial } \\
\text { cognition }\end{array}$ & $\begin{array}{l}\text { Article, which compares the mental representation of sound directions in } \\
\text { blind football players with blind non-athletes and sighted individuals. }\end{array}$ \\
\hline Webborn \& Emery (2014) & JA & $\begin{array}{l}\mathrm{APA} \\
\mathrm{SMe}\end{array}$ & Yes & Epidemiology, Paralympics & $\begin{array}{l}\text { Study focused on the analysis of the injuries suffered by some of the 4,000 } \\
\text { athletes who participated in the London } 2012 \text { Paralympic Games. }\end{array}$ \\
\hline $\begin{array}{l}\text { Zare, McMullen \& } \\
\text { Gardner-McCune (2014) }\end{array}$ & CSM & $\begin{array}{l}\text { CS } \\
\mathrm{MD}\end{array}$ & No & Sound, Football, Disability & $\begin{array}{l}\text { The aim of this work is to discover methods to help people with visual } \\
\text { impairments play football more efficiently and safely. The proposed system } \\
\text { uses headphone-rendered spatial audio, an on-person computer and sensors } \\
\text { to create 3D sound, which represents the objects on the field in, real-time. } \\
\text { This representation of the field will help players detect the location of objects } \\
\text { and people on the field more accurately. }\end{array}$ \\
\hline Twaddle (2014) & JA & SI & No & Football, Sport, Disability & $\begin{array}{l}\text { This article provides information on a 5-a-side football workshop held at the } \\
\text { Colorado School for the Deaf and Blind. The topics include teaching of } \\
\text { football fundamentals adapted to blind and deaf students, such as attacking } \\
\text { and defending rules and positions and basic skills. }\end{array}$ \\
\hline Nascimento (2014) & $\mathrm{AP}$ & SI & No & $\begin{array}{l}\text { Football for the blind, } \\
\text { Disability }\end{array}$ & $\begin{array}{l}\text { Project, which describes the experience of football practice for visually, } \\
\text { impaired people of B1 category. The fondness for football, the participation } \\
\text { in a UEPB project addressed to this population group in the period 2011- } \\
\text { 2014, together with the participation in events organized by the Brazilian } \\
\text { Blind Sports Confederation and the lack of scientific studies about football } \\
\text { for the visually impaired in Brazil were crucial to want to look for answers } \\
\text { and to work on adapted physical education and the development of football } \\
\text { for the visually impaired in Brazil. }\end{array}$ \\
\hline Suarez (2014) & JA & SI & No & Guide, Disability, Football & $\begin{array}{l}\text { Article, which analyzes the role of the guide in football for the blind. The } \\
\text { guide transmits the playing intensity for a better solution, generates trust in } \\
\text { the player and builds a code with him/her. It is, undoubtedly, one of the } \\
\text { most important roles within this sport. }\end{array}$ \\
\hline
\end{tabular}




\begin{tabular}{|c|c|c|c|c|c|}
\hline Fagher \& Lexell (2014) & JA & $\mathrm{SMe}$ & Yes & $\begin{array}{l}\text { Disability, Epidemiology, } \\
\text { Sports }\end{array}$ & $\begin{array}{c}\text { Article, which includes a systematic literature, search, a critical review and a } \\
\text { summary of current knowledge on the epidemiology of sports-related } \\
\text { injuries in athletes with disabilities and describes their characteristics, } \\
\text { incidence, prevalence, and prevention strategies. }\end{array}$ \\
\hline Van de Vliet (2014) & JA & $\mathrm{SMe}$ & Yes & Epidemiology, Paralympics & $\begin{array}{l}\text { The aim of this study is to report injury and illness incidence and } \\
\text { characteristics in Paralympic athletes. }\end{array}$ \\
\hline Campos et al. (2015) & JA & $\mathrm{SPh}$ & Yes & $\begin{array}{l}\text { Athlete evaluation, } \\
\text { Disability }\end{array}$ & $\begin{array}{l}\text { The purpose of this study was to assess the bilateral difference in force } \\
\text { production and the conventional ratio of knee flexor and extensor muscles at } \\
\text { different speeds in eleven footballers with visual impairments. }\end{array}$ \\
\hline De Moura et al. (2015) & JA & $\begin{array}{c}\mathrm{SH} \\
\mathrm{SI}\end{array}$ & Yes & Sport, Disability & $\begin{array}{c}\text { Literature review of studies which address football for people with visual } \\
\text { impairments. The studies analyzed were originally published in Portuguese } \\
\text { and English and the databases PubMed, SPORTDiscus, Web of Science and } \\
\text { Scopus, as well as Scielo electronic library and Google Scholar were } \\
\text { searched. }\end{array}$ \\
\hline Levandoski (2015) & JA & SI & No & $\begin{array}{l}\text { Football for the blind, } \\
\text { Disability, Guide, } \\
\text { Education }\end{array}$ & $\begin{array}{l}\text { The author describes the book by Souza, Campos and Gorla named Futebol } \\
\text { de 5: fundamentos e diretrizes. It was published in } 2014 \text { and consists of nine } \\
\text { chapters. }\end{array}$ \\
\hline Webborn et al. (2015) & JA & $\mathrm{SMe}$ & Yes & $\begin{array}{l}\text { Epidemiology, Paralympics, } \\
\text { Football }\end{array}$ & $\begin{array}{c}\text { Epidemiology of injuries in Paralympic football has received little attention. } \\
\text { A study concerning all sports included in the London } 2012 \text { Paralympic } \\
\text { Games identified 5-a-side football for the blind as the sport with the highest } \\
\text { injury rate. }\end{array}$ \\
\hline $\begin{array}{l}\text { Velten, Ugrinowitsch, } \\
\text { Portes, Hermann \& } \\
\text { Bläsing (2016) }\end{array}$ & JA & $\begin{array}{l}\text { MB } \\
\text { MD }\end{array}$ & Yes & $\begin{array}{l}\text { Football for the blind, } \\
\text { Disability, Sound, Spatial } \\
\text { cognition }\end{array}$ & $\begin{array}{l}\text { The aim of the paper was to compare the spatial concepts given to sound } \\
\text { directions by blind football players with both blind non-athletes and sighted } \\
\text { individuals. }\end{array}$ \\
\hline Gorla et al. (2017) & JA & $\mathrm{SPh}$ & Yes & $\begin{array}{l}\text { Athlete evaluation, } \\
\text { Disability, Sport }\end{array}$ & $\begin{array}{l}\text { Study that determines the somatotype profile and body composition of } \\
\text { athletes of the Brazilian national 5-a-side football team. }\end{array}$ \\
\hline
\end{tabular}

* Peer Reviewed; T Doctoral theses; B Books; BC Book chapters; AP Academic projects; CSM Congress and scientific meeting Publications; JA Journal articles; PD Patent documents; APA Adapted Physical Activity Science; SB Sport Biomechanics; CS Coaching Science; MB Motor Behavior; SL Sports Law; MD Motor Development, Motor Control and Motor Learning; SPh Sport Philosophy; SEPh Sport and Exercise Physiology; SMa Sport Management; SH Sport History; SI Sport Information; K Kinanthropometry; SMe Sport Medicine; SLF Sport and Leisure Facilities; SPe Sport Pedagogy; SEPs Sport and Exercise Psychology; SS Sport Sociology 